\title{
Potensi Beberapa Hidromakrofita Lokal untuk Meningkatkan Kualitas Air Lindi Tempat Pemrosesan Akhir Sampah Talangagung, Kecamatan Kepanjen, Kabupaten Malang
}

\author{
Retno Dewi Khinanty ${ }^{1)}$, Catur Retnaningdyah ${ }^{2)}$ \\ 1), 2) Laboratorium Ekologi dan Diversitas Hewan Jurusan Biologi, \\ Fakultas Matematika dan Ilmu Pengetahuan Alam, Universitas Brawijaya \\ Alamat korespondensi: ${ }^{1)}$ redtnno_eve@ymail.com dan ${ }^{2)}$ caturretnaningdyah@g.mail.com
}

\begin{abstract}
ABSTRAK
Tujuan penelitian ini adalah menentukan potensi hidromakrofita lokal sebagai agen fitoremediasi air lindi Tempat Pemrosesan Akhir (TPA) Sampah Talangagung Kecamatan Kepanjen Kabupaten Malang. Penelitian ini merupakan eksperimen dengan Rancangan Acak Lengkap (RAL) menggunakan lima perlakuan hidromakrofita lokal, yaitu kontrol (tanpa hidromakrofita), Ludwigia adscendens, Alternanthera sessilis, Typha angustifolia, dan polikultur ketiganya pada $25 \%$ air lindi dengan lima kali ulangan. Setiap perlakuan diinkubasi selama 30 hari di rumah kaca. Kualitas air lindi yang diamati adalah DO, turbiditas, nitrat, ortofosfat, dan BOD yang dipantau setiap enam hari sekali. Data tiap parameter dianalisis dengan uji beda antar waktu pantau pada masing-masing perlakuan. Semua hidromakrofita perlakuan mampu meningkatkan kualitas air lindi, yang ditandai dengan peningkatan nilai DO serta penurunan turbiditas, nitrat, ortofosfat, dan BOD. Hidromakrofita $L$. adscendens, T. angustifolia, dan polikultur (polikultur ketiga jenis tanaman) mampu menurunkan konsentrasi nitrat, ortofosfat, dan BOD sejak hari ke-12, sedangkan hidromakrofita $A$. sessilis sejak hari ke-18. Hidromakrofita $A$. sessilis mampu menurunkan $73,8 \%$ konsentrasi nitrat pada hari ke-30 dan $68,4 \%$ konsentrasi ortofosfat pada hari ke-24. Penurunan BOD $(61,4 \%)$ terbesar ditemukan pada perlakuan hidromakrofita $L$. adscendens dan $T$, angustifolia hari ke-30.
\end{abstract}

Kata kunci: Air lindi, fitoremediasi, hidromakrofita lokal, TPA

\section{ABSTRACT}

Objectives of this study are to determine the capability of some local hydro-macrophytes as phytoremediation agents for increasing leachate quality from Talangagung Landfill, Kepanjen, Malang. This was an experimental research using completely randomized design with five treatments: control, Ludwigia adscendens, Alternanthera sessilis, Typha angustifolia, and polyculture of three plants. The replication of treatment was five in the same time. Each treatment applied on $\mathbf{2 5 \%}$ leachate concentration and was incubated for 30 days. Measurements of leachates quality such as DO, turbidity, nitrates, orthophosphates, and BOD were performed every six days incubation. Data were analyzed by multiple comparison test among incubation day on each treatment. All of the hydro-macrophytes had an ability to increase the quality of leachate, which was reflected by increasing level of DO and decreasing level of turbidity, nitrates, orthophosphates, and BOD. Hydro-macrophytes L. adscendens, T. angustifolia, and polyculture of three plant species had optimum capability to reduce nitrates, orthophosphates, and BOD after 12 days of incubation, while $A$. sessilis after 18 days of incubation. Highest reduction percentage on nitrates $(73.8 \%)$ and orthophosphates $(68.4 \%)$ was found in $A$. sessilis on day 30 and 24 respectively. While the largest decreasing concentration of BOD $(61.4 \%)$ was found 30 days after incubation in the treatment of $L$. adscendens dan $T$. angustifolia.

Keywords: Hydromacrophytes, landfill, leachates, phytoremediation

\section{PENDAHULUAN}

Setiap hari manusia beraktivitas dan menghasilkan limbah domestik, seperti sampah dapur, deterjen, kertas, bungkus makanan, dan minuman. Limbah padat atau sampah umumnya akan dikumpulkan oleh Dinas Cipta
Karya dan dibawa menuju Tempat Pemrosesan Akhir (TPA) untuk diproses lebih lanjut, yaitu dibakar, ditimbun, atau pengolahan lainnya [1]. Tumpukan sampah akan mengeluarkan air lindi (leachate) sebagai hasil fermentasi anaerob [2]. Air lindi banyak mengandung 
bahan organik, ammonia-nitrogen, logam berat, bahan organik berklorin, senyawa anorganik, dan senyawa xenobiotic. Penurunan kadar bahan organik menjadi hal utama yang harus dilakukan sebelum membuang air lindi ke badan air [3].

TPA Wisata Edukasi Talangagung yang berada di wilayah Kepanjen Kabupaten Malang telah menampung air lindi pada kolam buatan dan selanjutnya diproses melalui empat tahap meliputi: (1) Proses anaerob; (2) aerasi dan pemberian koagulan; (3) sedimentasi atau pengendapan; dan (4) outlet, yaitu pemompaan air lindi untuk dikembalikan pada sel tumpukan sampah sebagai resirkulasi.

Tumbuhan banyak digunakan sebagai agen hayati untuk remediasi, sehingga teknologi ini disebut fitoremediasi. Hidromakrofita memiliki kemampuan menurunkan kadar pencemar, seperti logam berat, nitrat, fosfat, padatan, konduktivitas, dan turbiditas. Penurunan tersebut terjadi karena adanya pengambilan senyawa pencemar oleh tumbuhan dan diproses secara biologis melalui berbagai mekanisme [4].

Banyak jenis hidromakrofita yang berpotensi menjadi agen fitoremediasi. Polikultur Ludwigia hyssopifolia dan Ludwigia adscendens mampu meningkatkan kualitas air irigasi yang tercemar residu pupuk NPK yaitu dengan menurunkan kadar nitrat sebanyak $97,7 \%$, fosfat terlarut sebanyak $86,9 \%$, dan ammonium sebanyak $64,6 \%$ pada hari inkubasi ke-10 [5]. Polikultur Alternanthera sessilis dan L. adscendens mampu menurunkan kadar deterjen $92,7 \%$ pada inkubasi hari ke-15 [6]. Penanaman polikultur Typha angustifolia dengan Limnocharis flava, Fimbristylis globulosa, Vetiveria zizanoides, Equisetum ramosissium, Sesbania grandiflora, dan Scirpus grossus sepanjang $125 \mathrm{~m}$ pada saluran irigasi sawah selama 50 hari mampu menurunkan tingkat TDS sebanyak $10 \%$, kadar $\mathrm{KMnO}_{4}$ sebanyak $62,5 \%$, dan ortofosfat sebanyak $18 \%$ dibandingkan dengan kondisi air sebelum melewati hidromakrofita [7]. Beberapa jenis hidromakrofita tersebut termasuk tumbuhan lokal, sehingga aplikasinya tidak akan memberi dampak negatif bagi ekosistem lokal.

Hal tersebut menjadi dasar dilakukannya penelitian ini dengan tujuan untuk mengembangkan pengolahan air lindi TPA Talangagung menggunakan hidromakrofita lokal, yaitu L. adscendens (Krangkong), $A$. sessilis (Kremah), T. angustifolia (Embet), dan polikultur ketiganya sebagai agen fitoremediasi.

\section{METODE PENELITIAN}

Penelitian ini dilaksanakan pada bulan Agustus 2015 hingga Juni 2016. Hidromakrofita didapat dari sawah organik Kec. Kepanjen. Air lindi didapat dari kolam outlet (kolam ke-4) pengolahan air lindi TPA Wisata Edukasi Talangagung, Kec. Kepanjen, Kab. Malang. Aklimatisasi dan perlakuan tanaman dilakukan di rumah kaca. Pengukuran parameter fisiko-kimia dan analisis data dilakukan di Laboratorium Ekologi dan Diversitas Hewan, Jurusan Biologi, Fakultas Matematika dan Ilmu Pengetahuan Alam, Universitas Brawijaya Malang.

Perlakuan pada penelitian adalah tiga jenis hidromakrofita sebagai agen fitoremediasi yang diaklimatisasi terlebih dahulu pada bak berisi $30 \mathrm{~L}$ air sumur sampai tumbuh stabil. Proses aklimatisasi dilakukan selama \pm 20 hari. Selanjutnya, air sumur diganti dengan $25 \%$ air lindi dalam jumlah sama, yaitu $30 \mathrm{~L}$, sebagai unit percobaan. Air lindi dengan konsentrasi $25 \%$ dibuat dengan mengencerkan air lindi pekat dengan air sumur (1:4). Lima perlakuan dalam penelitian ini, yaitu: 1) Air lindi tanpa hidromakrofita (kontrol), 2) air lindi dengan hidromakrofita $L$. adscendens, 3) air lindi dengan hidromakrofita $A$. sessilis, 4) air lindi dengan hidromakrofita $T$. angustifolia, dan 5) air lindi dengan polikultur ketiga jenis hidromakrofita.

Masing-masing perlakuan diulang sebanyak lima kali, sehingga terdapat 25 unit percobaan. Hidromakrofita yang digunakan pada tiap perlakuan didasarkan luas penutupan yaitu $25 \%$ dari total luas permukaan bak, kemudian ditimbang untuk disamakan biomassanya pada ulangan dari hidromakrofita yang sama. Seluruh perlakuan diinkubasi selama 30 hari di rumah kaca. Pemantauan kualitas air lindi dilakukan secara periodik setiap enam hari sekali meliputi beberapa parameter seperti terlihat pada Tabel 1. Data tiap parameter dianalisis dengan uji beda antar waktu pantau pada masing-masing perlakuan. 
Tabel 1. Beberapa parameter kualitas fisikakimia air lindi yang dipantau selama penelitian

\begin{tabular}{lcl}
\hline & Satuan & \multicolumn{1}{c}{ Metode } \\
\hline Oksigen & $\mathrm{mg} . \mathrm{l}^{-1}$ & DOmeter \\
Terlarut (DO) & $\mathrm{NTU}$ & Turbidimeter \\
Turbiditas & $\mathrm{mg} \cdot \mathrm{l}^{-1}$ & Spektrofotometri \\
Nitrat & mg. $\mathrm{l}^{-1}$ & Spektrofotometri \\
$\begin{array}{l}\text { Ortofosfat } \\
\text { Biological }\end{array}$ & $\mathrm{mg} . \mathrm{l}^{-1}$ & DOmeter \\
$\begin{array}{l}\text { Oxygen } \\
\text { Demand (BOD) }\end{array}$ & & \\
\hline
\end{tabular}

\section{HASIL DAN PEMBAHASAN}

\section{Konsentrasi Oksigen Terlarut (DO) Air Lindi selama Proses Fitoremediasi}

Nilai DO pada semua perlakuan meningkat pada hari ke tiga $\left(2,52-5,31 \mathrm{mg} \cdot \mathrm{l}^{-1}\right)$, namun menurun drastis pada hari enam $(1,52-$ 2,20 mg..$\left.^{-1}\right)$ dan $12 \quad\left(0,53-0,81\right.$ mg..$\left.^{-1}\right)$, kemudian tidak banyak mengalami perubahan hingga akhir hari pengamatan (Gambar 2A). Selain itu tampak bahwa pada waktu inkubasi yang sama nilai DO pada kontrol cenderung lebih rendah dibandingkan perlakuan hidromakrofita dan ini membuktikan bahwa adanya hidromakrofita dapat sedikit meningkatkan DO air.

Peningkatan DO yang kurang optimal ini dapat disebabkan oleh jenis hidromakrofita yang digunakan dalam penelitian ini tergolong tipe emergent, dimana organ yang melakukan fotosintesis berada di atas permukaan air, sehingga oksigen hasil fotosintesis tidak langsung masuk ke dalam badan air. Adanya penguraian bahan organik, seperti daun atau batang tua, juga dapat menurunkan DO [8]. Peningkatan bahan organik yang berasal dari hidromakrofita yang mati dapat dikurangi dengan melakukan pemangkasan, sehingga merangsang pertumbuhan tunas lateral, pembuahan, dan pembungaan, sehingga akan muncul cabang muda. Tumbuhan berumur muda juga lebih efektif sebagai agen fitoremediator dibandingkan tumbuhan yang telah tua.

Air lindi hasil proses fitoremediasi ini masih belum dapat digunakan untuk air irigasi sebab nilai baku mutu DO berdasarkan Peraturan Pemerintah No 82 tahun 2001 untuk pertanian dan perikanan adalah $3 \mathrm{mg} \cdot \mathrm{l}^{-1}$ dan 4 mg. $1^{-1}$.

\section{Nilai Turbiditas Air Lindi selama Proses Fitoremediasi}

Nilai turbiditas pada perlakuan kontrol memiliki rentang antara 12,7-26,6 NTU, sedangkan pada perlakuan hidromakrofita memiliki rentang antara 5,1-22,1 NTU selama proses fitoremediasi (Gambar 2B). Peningkatan turbiditas yang terjadi pada awal inkubasi terjadi dikarenakan adanya blooming mikroalga yang tampak pada semua perlakuan, seperti dicontohkan pada Gambar 1. Secara keseluruhan, perlakuan hidromakrofita memiliki nilai turbiditas yang lebih rendah (5,1-22,1 NTU) dibandingkan kontrol (12,72,66 NTU). Hal tersebut menunjukkan proses fitoremediasi menggunakan hidromakrofita lokal mampu menurunkan turbiditas air lindi. Perlakuan dengan L. adscendens, mampu menurunkan nilai turbiditas secara signifikan pada pengamatan hari ke-18, sedangkan perlakuan $A$. sessilis, $T$. angustifolia, dan polikultur pada hari ke- 24 .

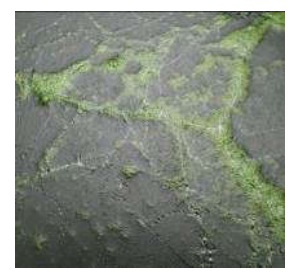

Gambar 1. Blooming mikroalga pada kontrol

Blooming mikroalga juga dapat menyebabkan nilai DO menurun disebabkan oleh adanya dekomposisi alga yang mati karena tidak mampu bersaing dalam perebutan sumber daya yang jumlahnya terbatas [9].

\section{Konsentrasi Nitrat Air Lindi selama Proses Fitoremediasi}

Perlakuan dengan $L$. adscendens awalnya memiliki konsentrasi nitrat sebesar 4,14 mg..$^{-1}$, kemudian berkurang secara signifikan menjadi $1,53 \mathrm{mg} \cdot 1^{-1}$ sejak hari ke-18 (Gambar 2C). Konsentrasi awal nitrat pada perlakuan $A$. sessilis lebih tinggi dibandingkan perlakuan lain, yaitu sebesar 5,71 mg. $\mathrm{l}^{-1}$, namun mampu diturunkan secara signifikan hingga $1,52 \mathrm{mg} . \mathrm{l}^{-1}$ pada hari ke-24. Perlakuan T. angustifolia mampu menurunkan konsentrasi nitrat secara signifikan menjadi 1,97 mg. $\mathrm{l}^{-1}$ pada hari ke-12, sedangkan konsentrasi nitrat perlakuan polikultur menurun menjadi $1,64 \mathrm{mg} . \mathrm{l}^{-1}$ pada hari ke-30. Perlakuan kontrol juga mengalami penurunan nitrat secara signifikan pada hari 


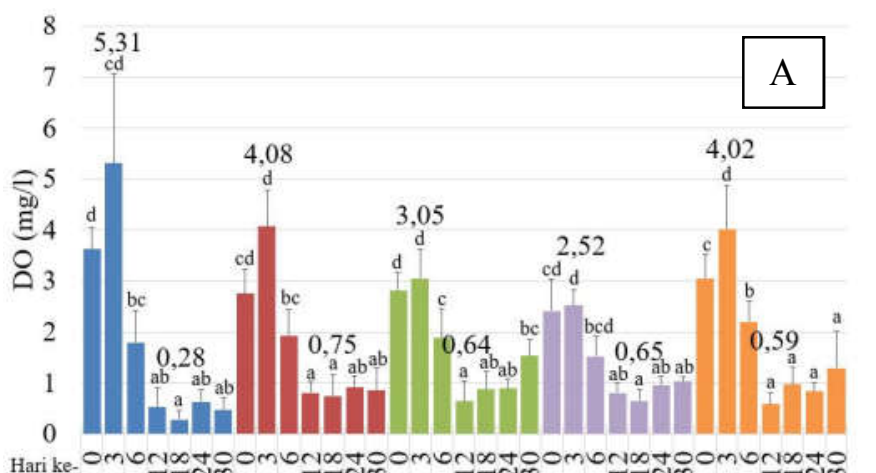

$\mathrm{K}$

Perlakuan Hidromakrofita

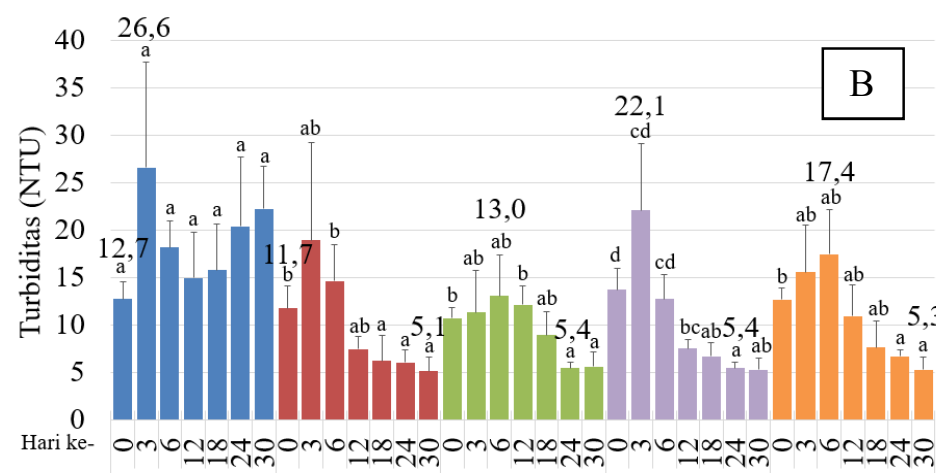

K

$\mathrm{L}$

A

$\mathrm{T}$

$\mathrm{P}$ Perlakuan Hidromakrofita

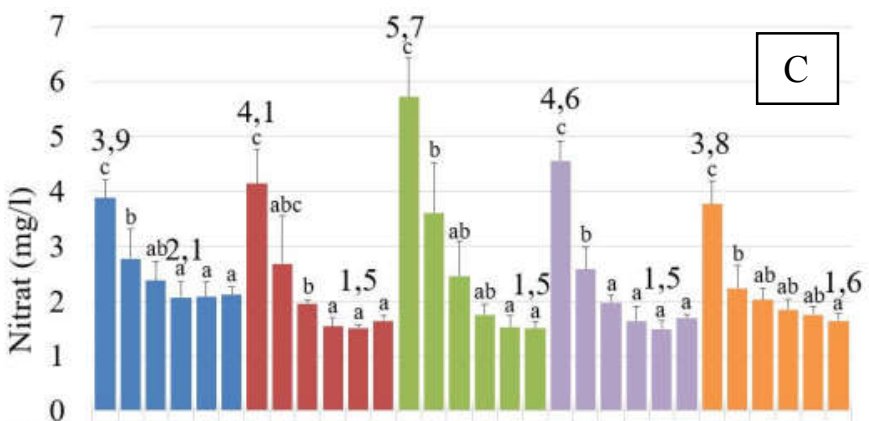

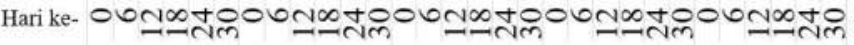
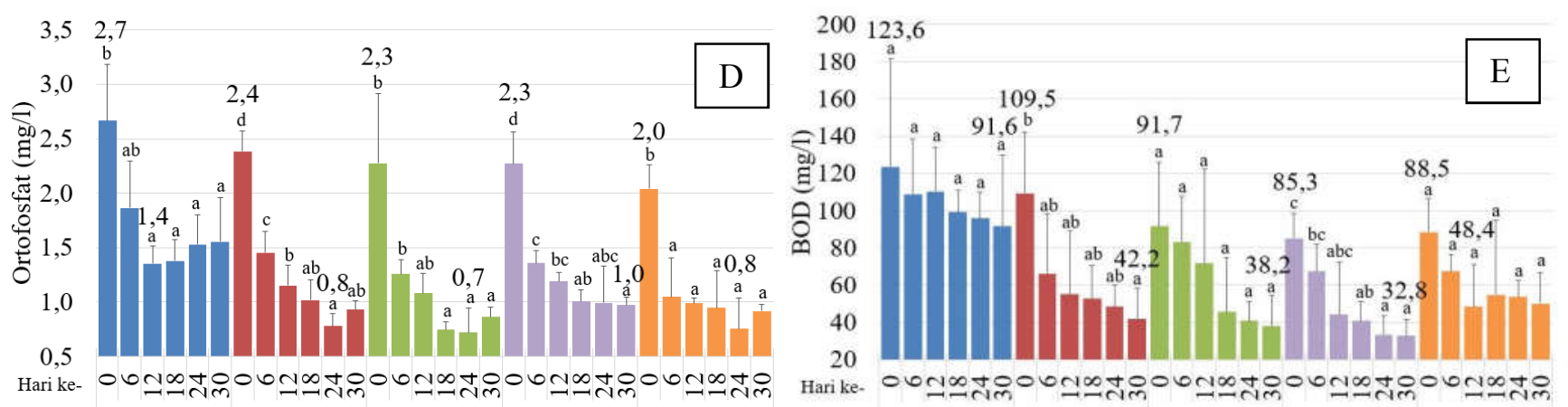

L

A

$\mathrm{L}$

(6)

Gambar 2. Konsentrasi DO (A); Turbiditas (B); Nitrat (C); Ortofosfat (D); dan BOD (E) air lindi tiap waktu pengamatan pada semua perlakuan. Keterangan:

Notasi yang sama pada masing-masing perlakuan hidromakrofita menunjukkan tidak berbeda nyata berdasarkan uji Brown-Forsythe yang dilanjutkan uji Games-Howell, $\alpha$ 0,05.

Tabel 2. Rata- rata persentase penurunan konsentrasi nitrat, ortofosfat, dan BOD pada tiap waktu pengamatan

\begin{tabular}{|c|c|c|c|c|c|c|c|c|c|c|c|c|c|c|c|}
\hline \multirow{2}{*}{ Perlakuan } & \multicolumn{5}{|c|}{ Penurunan Nitrat (\%) pada Hari ke- } & \multicolumn{5}{|c|}{ Penurunan Ortofosfat (\%) pada Hari ke- } & \multicolumn{5}{|c|}{ Penurunan BOD (\%) pada Hari ke- } \\
\hline & 6 & 12 & 18 & 24 & 30 & 6 & 12 & 18 & 24 & 30 & 6 & 12 & 18 & 24 & 30 \\
\hline Kontrol & 28,4 & 38,8 & 46,6 & 46,3 & 45,4 & 30,0 & 49,1 & 48,2 & 42,5 & 41,5 & 11,8 & 10,7 & 19,7 & 22,3 & 25,9 \\
\hline L. adscendens & 35,1 & 52,8 & 62,9 & 63,6 & 60,3 & 38,9 & 51,7 & 57,2 & 67,2 & 60,9 & 39,5 & 49,5 & 51,7 & 55,7 & 61,4 \\
\hline A. sessilis & 36,9 & 56,9 & 69,4 & 73,3 & 73,8 & 44,8 & 52,5 & 67,2 & 68,3 & 62,1 & 9,1 & 21,9 & 50,2 & 55,5 & 58,3 \\
\hline T. angustifolia & 43,3 & 56,7 & 63,9 & 67,2 & 62,8 & 40,1 & 47,6 & 55,7 & 56,2 & 57,1 & 20,9 & 48,2 & 51,9 & 60,6 & 61,5 \\
\hline Polikultur & 40,6 & 46,3 & 51,1 & 53,5 & 56,4 & 48,5 & 51,4 & 53,6 & 63,0 & 55,0 & 23,7 & 45,3 & 38,1 & 39,4 & 43,3 \\
\hline
\end{tabular}


ke-18. Hal ini dapat disebabkan oleh adanya pengambilan nitrat oleh mikroalga.

Mekanisme pengambilan nitrat dari lingkungan oleh tumbuhan dapat dilakukan secara fitoekstraksi maupun fitovolatilisasi. Fitoekstraksi merupakan mekanisme penyerapan nitrat oleh akar dan diakumulasi oleh organ, utamanya tunas, untuk pembentukan protein. Adanya proses fitovolatilisasi menyebabkan nitrat kembali diubah menjadi gas nitrogen dan dikembalikan ke atmosfer [10]. Penguraian bahan organik, seperti batang atau daun mati, oleh mikroorganisme akan menghasilkan ammonium yang dapat kembali menjadi nitrat [11].

\section{Konsentrasi Ortofosfat Air Lindi selama Proses Fitoremediasi}

Perlakuan kontrol memiliki konsentrasi ortofosfat dengan rentang 1,4-2,7 mg..$^{-1}$ selama waktu pengamatan, sedangkan konsentrasi ortofosfat pada perlakuan hidromakrofita adalah 0,7-2,4 mg. $\mathrm{l}^{-1}$ (Gambar 2D). Perlakuan kontrol, $L$. adscendens, $A$. sessilis, $T$. angustifolia, dan polikultur secara berurutan mampu menurunkan konsentrasi ortofosfat pada hari ke-12, 24, 18, 30, dan 6. Meskipun perlakuan hidromakrofita, kecuali polikultur, membutuhkan waktu lebih lama untuk menurunkan konsentrasi ortofosfat, namun penurunan menggunakan hidromakrofita lebih efektif. Polikultur merupakan fitoremediator yang memiliki kemampuan menurunkan konsentrasi ortofosfat lebih cepat dibandingkan hidromakrofita lain.

Penurunan ortofosfat terjadi karena tumbuhan membutuhkan fosfor sebagai bahan pembentukan energi. Sebaliknya peningkatan ortofosfat terjadi karena adanya ekskresi organisme perairan dan dekomposisi bahan organik, sehingga meningkatkan fosfat anorganik [12].

\section{Konsentrasi Biochemical Oxygen Demand (BOD) Air Lindi selama Proses Fitoremediasi}

Konsentrasi BOD pada perlakuan kontrol memiliki rentang antara 91,6-123,6 mg. ${ }^{-1}$, sedangkan pada perlakuan hidromakrofita memiliki rentang antara 532,8-109,5 mg. $\mathrm{l}^{-1}$ selama proses fitoremediasi (Gambar 2E). Penurunan secara signifikan pada perlakuan $L$. adscendens didapat pada pada hari ke-30, sedangkan untuk $T$. angustifolia pada hari ke24. Meskipun tidak berbeda secara signifikan, penurunan pada perlakuan $A$. sessilis dan polikultur juga relatif besar dibandingkan hari ke-0.

Turunnya BOD menunjukkan bahwa tingkat bahan organik juga telah menurun, sehingga kebutuhan mikroorganisme terhadap oksigen untuk penguraian juga menurun. Hal tersebut menunjukkan bahwa pencemaran oleh bahan organik telah menurun sebab adanya transformasi menjadi bahan yang digunakan oleh tumbuhan dan organisme perairan. Namun, kenaikan BOD juga terjadi meskipun tidak ada pemasukan limbah dari luar badan air. Penguraian batang atau daun yang mati akan meningkatkan BOD [13].

\section{Rekomendasi Perlakuan Fitoremediasi Air Lindi menggunakan Hidromakrofita Lokal berdasarkan Persentase Penurunan Nitrat, Ortofosfat, dan BOD}

Jenis pencemar yang mampu diturunkan secara efektif pada proses fitoremediasi air lindi pada penelitian ini adalah nitrat, ortofosfat, dan BOD. Penurunan konsentrasi nitrat pada perlakuan $L$. adscendens, $A$. sessilis, dan T. angustifolia, telah melebihi $50 \%$ pada hari ke-12 (Tabel 2). Perlakuan polikultur mampu menurunkan $50 \%$ konsentrasi nitrat pada hari ke-18. Persentase penurunan nitrat terbesar terdapat pada perlakuan $A$. sessilis, yaitu melebihi $70 \%$, sejak hari ke-24. Sementara itu, penurunan konsentrasi nitrat pada perlakuan kontrol tidak mencapai $50 \%$ hingga akhir inkubasi. Pengamatan hari ke-30 pada perlakuan kontrol, $L$. adscendens, dan $T$. angustifolia menunjukkan bahwa kemampuan reduksi nitrat menurun $( \pm 3,5 \%)$. Nitrat diambil oleh hidromakrofita sebagai sumber $\mathrm{N}$ dalam pembentukan asam nukleat dan protein. Mekanisme fitoremediasi dalam pengurangan nitrat dari lingkungan umumnya melalui fitoekstraksi oleh akar kemudian diakumulasi didalam tubuh (fitoakumulasi) atau melalui fitovolatilisasi dimana nitrat kembali diubah menjadi gas nitrogen dan dikembalikan ke atmosfer [10]. 
Penurunan konsentrasi ortofosfat pada perlakuan $L$. adscendens, A. sessilis, dan polikulur, telah melebihi $50 \%$ pada hari ke- 12 , sedangkan perlakuan $T$. angustifolia mampu menurunkan $50 \%$ konsentrasi ortofosfat pada hari ke-18 (Tabel 2). Persentase penurunan ortofosfat terbesar terdapat pada perlakuan $A$. sessilis, yaitu $68 \%$, pada hari ke-24. Perlakuan kontrol mengalami peningkatan konsentrasi ortofosfat sejak hari ke-18. Semua perlakuan hidromakrofita, kecuali T. angustifolia, mengalami peningkatan konsentrasi ortofosfat pada hari ke-30 ( $\pm 7 \%)$. Sebaliknya $T$. angustifolia mampu secara terus menurunkan konsentrasi ortofosfat hingga akhir pengamatan. Seperti halnya nitrat, ortofosfat diambil oleh hidromakrofita melalui akar dan diakumulasi untuk diambil sebagai unsur fosfor dalam pembentukan energi [12].

Perlakuan $L$. adscendens, A. sessilis, dan T. angustifolia, mampu menurunkan konsentrasi BOD lebih dari 50\% sejak hari ke18 (Tabel 2). Penurunan terbesar terlihat pada perlakuan $T$. angustifolia dan $L$. adscendens pada hari ke-30, yaitu 61\%. Perlakuan polikultur hingga akhir pengamatan tidak mampu menurunkan nilai BOD hingga $50 \%$. Begitu pula untuk perlakuan kontrol yang hanya mampu menurunkan BOD tertinggi pada $25 \%$ hingga akhir pengamatan.

Kemampuan L. adscendens dalam menyerap bahan pencemar dapat dipengaruhi oleh kondisi morfologi. Hidromakrofita $L$. adscendens memiliki batang tegak di atas air, namun sebagian batangnya juga tumbuh vertikal. Akar L. adscendens muncul pada setiap nodus batang. Selain akar utama, nodus batang juga mengeluarkan banyak akar mengapung, disebut pneumatophore, yang menjangkau banyak tempat [14].

A. sessilis baik digunakan untuk fitoremediasi. Meskipun merupakan tumbuhan emergent dan hanya akar yang dapat memiliki kontak dengan bahan pencemar di air atau tanah, namun $A$. sessilis memiliki sistem perakaran yang dapat menjangkau area luas. Akar utamanya merupakan akar tunggang, namun pada batang vertikal merambat (creeping) di permukaan air terdapat akar adventif yang muncul di setiap nodus [15].

Sistem perakaran $T$. angustifolia terdiri dari rhizomatous rootstock dan akar serabut. Rhizomatous rootstock merupakan batang yang tumbuh horizontal dibawah air atau tanah, serta pada setiap nodusnya dapat tumbuhan akar dan tunas baru. Adanya rhizomatous rootstock menyebabkan hidromakrofita ini tumbuh menggerombol dan sulit dipisahkan antar tunas. Sistem perakaran kompleks tersebut menyebabkan tumbuhnya akar yang kuat dan menjangkau area luas [16].

\section{KESIMPULAN}

Hidromakrofita lokal jenis $L$. adscendens, A. sessilis, T. angustifolia dan polikultur ketiganya mampu meningkatkan kualitas air lindi, ditandai terjadinya kenaikan nilai DO serta penurunan turbiditas, nitrat, ortofosfat, dan BOD. Hidromakrofita L. adscendens dan T. angustifolia, dan polikultur memiliki kemampuan menurunkan konsentrasi nitrat, ortofosfat, dan BOD sejak hari ke-12, sedangkan hidromakrofita $A$. sessilis pada sejak ke-18. Hidromakrofita $A$. sessilis mampu menurunkan $73,8 \%$ konsentrasi nitrat pada hari ke-30 dan $68,4 \%$ konsentrasi ortofosfat pada hari ke-24. Penurunan BOD terbesar terdapat pada $L$. adscendens dan $T$. angustifolia hari ke$30(61,4 \%)$.

\section{UCAPAN TERIMAKASIH}

Penulis mengucapkan terimakasih kepada: (1) pimpinan Tempat Pemrosesan Akhir (TPA) Sampah Talangagung, Kecamatan Kepanjen, Kabupaten Malang yang telah mengijinkan pengambilan air lindi untuk perlakuan; (2) Gilang Indra Wahyudi, S.Si dan Purnomo, SSi. yang telah membantu selama penelitian.

\section{DAFTAR PUSTAKA}

[1] Liermann, T.A. 2009. Fiji Islands' Naboro Landfill Leachate Quality Analysis and the Applicability of Developed versus Small Island Developing State Discharge Standards. Michigan Techology University. Michigan. Report.

[2] Koderi. 2015. Rekayasa Sistem Pengelolaan dan Pemanfaatan Biogas di Kawasan TPA Wisata Edukasi Kepanjen. Pengelolaan Lingkungan Universitas Brawijaya. Tesis.

[3] Renou, S., J.G. Givaudan, S. Poulain, F. Dirassouyan, \& P. Moulin. 2008. Landfill Leachate treatment: Review and Opportunity. Journal of Hazardous Material. 150: 468-493. 
[4] Dhir, B. 2013. Phytoremediation: Role of Aquatic Plants in Environmental CleanUp. Springer India. New Delhi.

[5] Ivansyah, K. \& C. Retnaningdyah. 2013. Potensi Hidromakrofita Lokal untuk Peningkatan Kualitas Air Irigasi Tercemar Residu Pupuk NPK dengan Sistem Batch Culture. Jurnal Biotropika. 1 (3): 80-84

[6] Fajarianingtyas, D.A, C. Retnaningdyah, \& E. Arisoesilaningsih. 2013. Peningkatan Kualitas Limbah Deterjen dengan Fitoremediasi Menggunakan Diversitas Hidromakrofita. Lentera Sains. 2 (2).

[7] Prasetyo, H.D. \& C. Retnaningdyah. 2013. Peningkatan Kualitas Air Irigasi Akibat Penanaman Vegetasi Riparian dari Hidromakrofita Lokal selama 50 Hari. Jurnal Biotropika. 1 (4): 149-153.

[8] Effendi, H. 2003. Telaah Kualitas Air Bagi Pengelolaan Sumber Daya dan Lingkungan Perairan. Edisi kelima. Kanisius. Yogyakarta.

[9] Gupta, P., S. Roy, \& A. B. Mahindrakar. 2012. Treatman of Water Usimg Water Hyacinth, Water Lettuce, and Vetiver Grass - A Review. Resources and Environment. 2 (5): 202-215.

[10] Pivetz, B.E. 2001. Ground Water Issues: Phytoremediation of Contaminated Soil and Ground Water at Hazardous Waste. Environmental Protection Agency. Washington.

[11] Oms, M.T., A. Cerdà, \& V. Cerdà. 2000. Handbook of Water Analysis: Analysis of Nitrites and Nitrates. Marcel Dekker, Inc. New York.

[12] Spellman, F.R. 2013. Handbook of Water and Wastewater Treatment Plant Operation. Edisi ketiga. CRC Press. Washington.

[13] Mahida, U.N. 1993. Pencemaran Air dan Pemanfaatan Limbah Industri. PT Raja Gravindo Persada. Jakarta.

[14] Oziegbe, M. \& J. O. Faluyi. 2012. Reproductive biology of Ludwigia leptocarpa and $L$. adscendens subsp. Diffusa in Ile Ife, Nigeria. Turkey Journal Botany. 26: 167-173.

[15] Sinha, S., R. Saxena, \& S. Singh. 2002. Comparative Studies on Accumulation of $\mathrm{Cr}$ from Metal Solution and Tanneru Effluent under Repeated Metal Exposure by Aquatic Plants: Its Toxic Effects. Environmental Monitoring and Assessment. 80 (1): 17-31.

[16] Runkel, S.T. \& D. M. Roosa. 2015. Wildflowers and Other Plants of Iowa Wetlands. Edisi kedua. University of Iowa Press. Iowa. 